\title{
Wayang Multimedia: Wayang Contemporary Art as a Creative Art-Industrial in Modern Era
}

\author{
Djoko Sulaksono $^{1}$, Kenfitria Diah Wijayanti' ${ }^{2}$, and Bagus Wahyu Setyawan ${ }^{3}$ \\ \{ciptaningmintaraga@yahoo.com¹,kenfi3a@ymail.com², \& bagusws93@gmail.com ${ }^{3}$ \} \\ ${ }^{1,2,3}$ Universitas Sebelas Maret, Surakarta, Indonesia
}

\begin{abstract}
Wayang being one of Javanese traditional art who become extinction. The dominant factor are the entering new form of art which more interested viewed from the show-packaging. Wayang multimedia try to combine the Wayang traditional art with newest technology for make the new form of Wayang performing which more interested by the community. This research aimed to describe and explain about contemporary Wayang as an alternative ways for creative art-industrial in modern era. Form of this research is descriptive qualitative which source of data are Wayang multimedia performing. Data collected using observation and in-depth interview with some expert in Wayang and dalang to support data analysis. Result of this research find that Wayang multimedia as a Wayang performing which combine the Wayang traditional art using audio and visual technology, such as sound system, projector to show the background of story, lighting technology to make Wayang staging become interesting, also using cinematography technique. In the staging of Wayang multimedia not whole using all the puppet character, because some of character replace with video illustration showed by projector. Wayang multimedia staging in greater demand by the community because more varied, creative, and more interested with using some of modern technology.
\end{abstract}

Keywords: wayang multimedia, contemporary wayang art, creativity artindustrial, technological development

\section{INTRODUCTION}

The phenomenon of declining public interest on traditional arts is become concern. Traditional arts such as wayang, kethoprak show, ludruk, wayang wong, and others have not been in public demand. As a result, there are a small numbers of audiences when performing traditional arts [1]. This cannot be separated from the existence of traditional arts with more modern and newer packaging. Those result in traditional arts increasingly not becoming the favorite choice of society. Most of their favorite arts are originally from other cultures also the other country which are far from customs and tradition values [2]. A survey conducted by the writer shows that almost $80 \%$ of youth in adolescence prefer to watch modern art shows rather than watching the traditional one. Theater, film, modern dance, and fashion show are considered 
more interesting than traditional art show such as wayang kulit, ludruk, kethoprak, karawitan art show.

Beside external factors, there is also internal factor dealing with monotonous wayang show. Along with times, the shows remain similar to the previous, there is no improvement in traditional arts. The structure of wayang show tends to be rigid resulted in the lack of public interest to watch it [3]. The audiences are limited to wayang fans group, wayang art practitioners, young people who take a study on wayang or puppetry art. Those factors make many people bored and turned into the more modern and interesting art, especially young generation. As a consequence, it is necessary to take an effort in re-actualizing traditional arts, especially Javanese, so traditional arts can be accepted by society. This effort also becomes reservation and conservation of traditional arts to avoid the threat of extinction. Regarding to the situation that in some regions, many traditional arts have been vacuum and stopped to perform, the absence of traditional art practitioners and enthusiasts become a major reason [4].

One of efforts on re-actualizing traditional arts is to create a new form of traditional art in order to attract public interest. This new form is certainly adjusted to public interest. Traditional art is an art which has standard forms and rules. The new form of traditional art is proposed by creating innovation of traditional arts without distorting and changing standard and essential of traditional art. Changing form and packaging of traditional art show becomes contemporary art without losing essential and soul of traditional art [5]. Technology development will directly and indirectly affect human life style into digital life style. It implies that human life style will become the effect and cause of technology usage [6]. Consequently, practitioners of wayang art are necessary to address and to consider it to create a multimedia wayang art show categorized as contemporary art by combining wayang traditional art and some multimedia technologies with the employment of electronic devices.

Multimedia wayang is a form of contemporary wayang arts combining traditional art and modern technology. The technology used is multimedia technology including audio media, visual media, audio-visual media, and flash multimedia. The employment of some modern technologies can expectedly attract public interest and adapt to the times. Each aspect of human life in this modern era cannot be separated from the influence of technology and electronic devices. The employment of electronic devices in human activities can rapidly change human behavior in terms of social, economy and culture. Human life become more advance and modern, so human activities in various fields become a borderless relations [7].

\section{METHOD}

This study is descriptive qualitative with the main focus to describe and to explain Multimedia Wayang Show categorized as contemporary wayang art show as an alternative performing art in the modern era. The main data source is multimedia wayang art show. Data collection technique utilized observation and in depth interview with experts and practitioner of wayang show, including dalang, and wayang enthusiasts. Data triangulation was utilized to check data validity by utilizing other thing [8]. Triangulation technique used were triangulation of data source and theory. Data analysis technique employed interactive chain analysis with the steps including data collection, data reduction, data presentation, and drawing conclusion.

\section{RESULT AND DISCUSSION}

Wayang is one of arts emerging and developing from Javanese society. It is one of local wisdoms of Javanese culture acknowledged by UNESCO as a Masterpiece of Oral and Intangible Heritage of Humanity originally from Indonesia [9]. Wayang in Indonesia has some 
variations and types, including wayang kulit, wayang panji, wayang golek, wayang wahyu, wayang krucil, wayang suket, and others. Those have differences in terms of shapes, showpackaging and stories. However, the most popular one is wayang kulit purwa or known as ringgit purwa.

Multimedia wayang art show is a combination of conventional wayang kulit purwa show and multimedia technology. The employment of multimedia technology in multimedia wayang show aims to create a new form and packaging of wayang kulit purwa show in order to be more acceptable and attractive [10]. Multimedia wayang as a form of contemporary wayang uses some multimedia technology devices without eliminating the essential and soul of wayang show. Dalang and some wayangs are still used in multimedia wayang show. Besides, the accompaniment music of multimedia wayang show still uses gamelan music with gendhinggendhing as accompaniment instrument similarly used in conventional wayang kulit show. Hence, when society watch multimedia wayang show they will realize the similar show as usual. The choice of gendhing-gendhing is also adjusted to pathet or scene sequences in multimedia wayang kulit.

Multimedia wayang show is done by combining conventional wayang show technique with some multimedia technologies [11]. Multimedia technologies used in conventional wayang include audio media, visual media, audio-visual media and macromedia flash. Audio technology is used by giving voice effect at the show and using electric sound system to give audience the access of dalang's voice and the accompaniment music. Visual technology used is modern lighting technology, screen projector and other visual effects. Furthermore, macromedia flash technique is used to produce animation video for wayang background showing some scenes of multimedia wayang story. Some multimedia usages will be explained as follow:

\subsection{The use of Audio Media in Multimedia Wayang Show}

Audio technology used is electric sound system which can make wayang voice clearer and accessed by all audiences. Dalang is one of keys in wayang show because dalang's job is a single story teller, who manages the plot, plays all characters, sets show rhythm and creates joke attracting audiences' sympathy [12]. Dalang's voice must be hearable by the audiences. If it is not, wayang show cannot run well and maximally because the message does not delivered.

The use of electronic sound system can support dalang's voice in order to be accessed by audiences. Conversely, without using sound system, dalang's voice is restricted and cannot be accessed by audiences staying far from stage [9]. Besides, sound effect is used to add realistic and artistic effects in multimedia wayang show. It also functions as an illustration describing emotional condition of certain scene in the show. By using sound effect, the audiences are conditioned as if they watch and feel the scene in multimedia wayang show, so it stimulates catharsis effect in multimedia wayang show audiences.

\subsection{The use of Visual Media in Multimedia Wayang Show}

Visual media used are screen projector used as a supplementary of kelir (curtain background in wayang show). Screen projector can show the more real scene background by projecting the scene from projector. For example, setting of screen containing in kingdom, keputren, forest, padepokan, and battlefield atmosphere. Therefore, by using screen projector technology which can be changed, the background can show background adjusted with scene, such as atmosphere of kingdom, keputren, forest, etc.

While visual media make the scene of multimedia wayang have an artistic effect, the scene become more alive and realistic. The audiences' imagination also will be exploited to follow the scene played in the show [13]. Consequently, wayang show become not monotonous. 
Besides, the modern lighting technique showing lamp variation also adds artistic effect in the show. In conventional wayang show, lighting technique only uses one light source known as blencong. However, the light from blencong is less interesting and seems dim [14]. Hence, the audiences with long distance slightly enjoy the show because they cannot see the show clearly. With modern lighting technique, multimedia wayang show become more various and interesting. The effect from lighting can give different show-packaging from the usual one. The use of modern lighting technique is also one of aspect used to attract public sympathy and interest to watch wayang show.

\subsection{The use of Audio-Visual Media (Macromedia Flash) in Multimedia Wayang Show}

Audio visual media used is the combination of video technique with using macromedia flash. The scenes of multimedia wayang show do not always run by dalang, they run with showing video created in macromedia flash and dalang only needs to narrate those scenes. Macromedia flash technique is an application or software used in the process of creating or editing video. It can change some motionless pictures to be the sequence of motion pictures or video [15]. In multimedia wayang show, not all scenes are performed with using wayang kulit purwa moved by dalang. Some scenes are performed in the form of video created before with the employment of macromedia flash application. This video is in the form of animation video containing and telling the stories of multimedia wayang scenes.

The role of dalang during video playback is only as a dubbing. Dalang only dubs when the wayang figures' dialog is playing in the video. When suluk and janturan run, dalang still carries out the duties. The role of dalang becomes lighter because s/he only plays a role as a dubbing and does not need to move wayang figures. Besides, the video created with the employment of macromedia flash is also used as the background of scenes, such as battlefield background and sky background drawing clouds movement [16]. The employment of macromedia flash technique is to make video and background of the scenes in multimedia wayang show become not monotonous show because there are some variations of scenes that can be enjoyed by all people [17]. By monotonous multimedia wayang show, society seem to watch a film scene in theatre, but the story and the aspect of wayang art still exist.

\section{CONCLUSION}

Multimedia wayang are a new form of wayang show, especially wayang kulit. It combines conventional puppet show with modern multimedia technology. It uses audio media, visual media, audio-visual media, and macromedia flash technologies. There are several habits and variations in multimedia wayang show, including the use of sound effects, projector screens for screen replacement to create a more realistic scene setting, and macromedia flash technology as a wayang scene video player. The novelty indicates that multimedia wayang show more varied and adds an artistic and realistic effects. Furthermore, with the existence of new variations and packaging in multimedia wayang show, it increases public interest in watching wayang show.

\section{REFERENCE}

[1] B.W. Setyawan, K. Saddhono, and A. Rakhmawati, "Sociological Aspects and Local Specificity in the Classical Ketoprak Script of Surakarta Style", Journal of Language and Literature, Vol. 17, No 2, pp. 141-153, 2017. 
[2] D. Sulaksono and K. Saddhono, "Ecological Concept of Wayang Stories and the Relation with Natural Conservation in Javanese Society”, KnE Social Sciences, Vol. 3, No. 9, pp. 58-63, 2018.

[3] D. A. Ghani, "Digital Puppetry: Comparative Visual Studies between Javanese \& Malaysian Art", International Journal of Applied Engineering Research, Vol. 13, No. 6, pp. 3579-3589, 2018.

[4] Soetarno and Sarwanto, Wayang Kulit dan Perkembangannya, Surakarta: ISI Solo Press in collaboration with CV. Cenderawasih Sukoharjo, 2010.

[5] M. Cohen, "Contemporary "Wayang" in Global Contexts", Asian Theatre Journal, Vol. 24, No. 2 (Fall, 2007), pp. 338-369, 2007.

[6] S. Tatminingsih, "The Impact of ICT Use on Early-Age Children Behavior: A Case Study of 4-7 Years Old" Jurnal Pendidikan, Vol. 18, No. 1, 2017.

[7] R. Bowen, "Artificial Darkness, an Obscure History of Modern Art and Media", Millennium Film Journal, Vol. 65, 2017.

[8] L. J. Moleong, Metodologi Penelitian Kualitatif (Edisi Revisi), Bandung: PT Remaja Rosdakarya, 2014.

[9] D. Ghani, "The Art of Noise: Understanding Digital Sound Effects in Wayang Kulit (Shadow Puppets)", International Review of the Aesthetics and Sociology of Music, Vol. 47, No. 1, pp. 137-149, 2016.

[10] I. N. Sedana, "Innovation of Wayang Puppet Theatre in Bali", Indigenous Culture, Education and Globalization, pp. 67-80, 2016.

[11] E. Bogaerts, "Mediating the Local: Representing Javanese Cultures on Local Television in Indonesia", Journal of Southeast Asian Studies, Vol. 48, No. 2, pp. 196-218, 2017.

[12] D. Sulaksono, "Filosofi Pertunjukan Wayang Purwa", JURNAL IBDA: Jurnal Kebudayaan Islam, Vol. 11, No. 2, 2013.

[13] J. Darmawan and I. Harnoko, "Design of Gradual Contemporary Wayang Visual Character Indonesia for Sticker Chatting and Game Applications", Journal of Game, Game Art, and Gamification (JGGAG), Vol. 2, No. 1, 2017.

[14] P. Primiceri and P. Visconti, "Solar-powered LED-based lighting facilities: an overview on recent technologies and embedded IoT devices to obtain wireless control, energy savings and quick maintenance", Journal of Engineering and Applied Sciences $A R P N$, Vol. 12, No. 1, pp. 140-150, 2017.

[15] H. Kresnadi, et al. "Interactive Teaching Material Development Training Using Macromedia Flash 8 for Teacher-Working Group Based on ICT in The Elementary School in District of Pontianak City", JPKM (Jurnal Pengabdian Kepada Masyarakat) UNTAN, Vol. 1, No. 2, pp. 34-37, 2018.

[16] M. Milovanovic, et al. "Computer tools in engineering education-example on Macromedia Flash", Acta Technica Corviniensis-Bulletin of Engineering, Vol. 10, No. 1, pp. 77, 2017.

[17] K. Saddhono, S. T, Widodo, M. T. Al Makmun, and M. Tozu, "The study of philosophical meaning of batik and kimono motifs to foster collaborative creative industry." Asian Soc. Sci. vol. 10 no. 9 pp 52-61, 2014 